\title{
ALW-II-41-27, an EphA2 inhibitor, inhibits proliferation, migration and invasion of cervical cancer cells via inhibition of the RhoA/ROCK pathway
}

\author{
XIANG LI ${ }^{1 *}$, DAN LI$^{2 *}$ and RONG MA ${ }^{2}$ \\ ${ }^{1}$ Department of Gynecology, The Third Xiangya Hospital of Central South University, Changsha, Hunan 410013; \\ ${ }^{2}$ Department of Gynecology, Affiliated Hospital of Traditional Chinese Medicine of Xinjiang Medical University, \\ Urumqi, Xinjiang Uygur Autonomous Region 83000, P.R. China
}

Received June 24, 2021; Accepted September 7, 2021

DOI: $10.3892 / \mathrm{ol} .2022 .13249$

\begin{abstract}
Recent studies have shown that the Eph receptor A2 (EphA2) and its inhibitor ALW-II-41-27 could regulate various cellular processes in several types of cancer. However, the manner in which ALW-II-41-27 affects the development of cervical cancer (CC) remains unknown. The present study aimed to evaluate the role of ALW-II-41-27 in inhibiting the proliferation, invasion and migration of human papilloma virus-positive $\mathrm{CC}$ cells and to verify whether Ras homolog family member A (RhoA)/Rho-associated protein kinase (ROCK) may be a crucial pathway involved in this process. Reverse transcription-quantitative PCR and western blotting analyses indicated an upregulation of EphA2 expression in $\mathrm{CC}$ cell lines (HeLa and CaSki). Furthermore, the results from MTT and colony formation assays indicated that ALW-II-41-27 inhibited cell proliferation. Results from wound healing and Transwell assays further demonstrated the inhibitory effect of ALW-II-41-27 on CaSki and HeLa cell migration and invasion, respectively. Furthermore, ALW-II-41-27 inhibited the protein expression of GTP-RhoA and ROCK1 in CaSki and HeLa cells. In addition, the ALW-II-41-27-induced inhibition of the biological function of CaSki and HeLa cells was promoted by cell co-culture with RhoA and ROCK inhibitors. Taken together, the present findings revealed that ALW-II-41-27 inhibited CC cell proliferation, migration and invasion by blocking the RhoA/ROCK pathway. These findings provide further insight into the mechanism of CC progression and
\end{abstract}

Correspondence to: Dr Xiang Li, Department of Gynecology, The Third Xiangya Hospital of Central South University, 138 Tongzipo Road, Changsha, Hunan 410013, P.R. China

E-mail: lidanldld2020@163.com

*Contributed equally

Key words: ALW-II-41-27, Eph receptor A2, Ras homolog family member A/Rho-associated protein kinase, proliferation, migration, invasion, cervical cancer significant information for the development of potential therapeutic targets for CC.

\section{Introduction}

Cervical cancer (CC) is the second most common malignant tumor diagnosed in women worldwide $(1,2)$. The recognition of human papillomavirus (HPV) as a primary cause of CC led to the development of HPV testing. There has been a shift from reflex HPV testing for mild cytological abnormalities, to co-testing with cytology and HPV, and lately to primary HPV screening (3). In the past decade, the popularization of CC screening has effectively improved the efficiency of diagnosis and treatment, while reducing the mortality rate. However, the number of new $\mathrm{CC}$ cases exhibits an annual increasing trend worldwide. In China, it is estimated that nearly 100,000 new diagnosed cases and $>30,000$ cases of CC-associated mortality occur each year (4). Advances in surgery, chemotherapy and postoperative radiotherapy have contributed to a 5 -year survival rate of $\sim 80 \%$. However, the actual long-term outcome of clinical treatment is not satisfactory. The high metastatic rate of $\mathrm{CC}$ reduces this result to $<50 \%(5,6)$. The clinical difficulties in $\mathrm{CC}$ treatment highlight the importance of identifying novel key biomarkers of CC, unraveling the pathogenetic mechanism of this disease and improving the treatment strategies.

The Eph receptor A2 (EphA2) is a transmembrane receptor tyrosine kinase, which has been shown to be elevated in several types of cancer. For example, it is positively correlated with the aggressive behavior of certain cancer cells, including malignant melanomas, breast cancer, pulmonary cancer, prostate cancer and esophageal cancer (6-11). These previous studies have reported high expression levels of EphA2 in both tissue and cell models of these diseases. This elevated expression level was shown to be associated with high histological grade, lymph node metastasis and poor prognosis in the aforementioned tumors (6-11). Upregulation of EphA2 and moderate or high expression of EphrinA-1 in squamous cervical carcinoma are associated with shorter overall survival, suggesting that they could be used as valuable prognostic markers (12). ALW-II-41-27 is a newly developed ATP-competitive 
EphA2 inhibitor (13). ALW-II-41-27 and small interfering RNA (siRNA)-based downregulation of EphA2 can effectively inhibit conditioned medium of cancer-associated fibroblast-induced gastric tumorigenesis (14). EphA2-siRNA inhibits proliferation and induces cell cycle arrest in SBC-5 cells by interfering with EphA2 gene expression (15). Similarly, ALW-II-41-27 and the tyrosine kinase inhibitor dasatinib inhibit the proliferation of EphA2-positive small cell lung cancer cells by downregulating EphA2 gene expression (15). Based on this evidence, the present study aimed to explore the mechanism by which ALW-II-41-27 may inhibit tumor progression in $\mathrm{CC}$.

According to a recent study, EphA2 antagonism can notably inhibit lipopolysaccharide-induced Ras homolog family member A (RhoA)/Rho-associated protein kinase (ROCK) activation in lung tissues, whereas antagonism of EphA2 can be used as a therapeutic method for acute lung injury (16). In addition, G12 protein stimulation can promote CC invasion via RhoA/ROCK/JNK activation (17). Inhibition of triple functional domain protein expression markedly decreases the migratory and invasive abilities of $\mathrm{CC}$ cells and the expression levels of the RhoA/ROCK signal transduction factors [RhoA, ROCK and phosphorylated (p)-LIM kinase] that in turn contribute to cell migration and invasion (18). It has been demonstrated that human squamous CC tissues overexpress RhoA and ROCK-I/II, whereas RhoA promotes CC cell progression and tumor growth (19). RhoA/ROCK is therefore considered as an important pathway associated with EphA2-related CC development.

The present study aimed to explore the role of ALW-II-41-27 in human CC cells and to determine its underlying mechanism. The findings from this study may provide further insight into the mechanism of $\mathrm{CC}$ progression and offer a promising therapeutic target for the treatment of this disease

\section{Materials and methods}

Cell culture and treatment. The human CC HeLa, CaSki and C33A cell lines, and the non-cancerous ectocervical epithelial Ect1/E6E7 cell line, were purchased from The Cell Bank of the Type Culture Collection of The Chinese Academy of Sciences. These cell lines were maintained in RPMI-1640 medium (Gibco; Thermo Fisher Scientific, Inc.) supplemented with 10\% FBS (Gibco; Thermo Fisher Scientific, Inc.) and 1\% penicillin/streptomycin (Invitrogen; Thermo Fisher Scientific, Inc.) and placed at $37^{\circ} \mathrm{C}$ in a humidified incubator containing $5 \% \mathrm{CO}_{2}$.

The EphA2 inhibitor ALW-II-41-27 (MedChemExpress) was dissolved in sterile DMSO (10 mmol/l stock solution) and stored in aliquots at $-20^{\circ} \mathrm{C}$. CaSki and HeLa cells were treated with 200,600 or $1,000 \mathrm{nM}$ ALW-II-41-27 for 24, 48 or $72 \mathrm{~h}(20)$. The activation of the RhoA/ROCK pathway was achieved by pretreatment of these two cells with the RhoA/ROCK signaling agonist phorbol 12-myristate 13-acetate (PMA; 100 ng/ml; Sigma-Aldrich; Merck KGaA) for $30 \mathrm{~min}$. The expression levels of EphA2, RhoA and ROCK were attenuated following treatment of these two cells with the RhoA inhibitor $\mathrm{C} 3$ transferase $(5 \mu \mathrm{g} / \mathrm{ml}$; Cytoskeleton Inc.) or ROCK blocker hydroxyfasudil (10 $\mu \mathrm{M}$; Tocris Bioscience) for $2 \mathrm{~h}$. These compounds were selected for cell pretreatment based on a previous study (21).
Reverse transcription-quantitative $(R T-q) P C R$. TRIzol ${ }^{\circledR}$ reagent (Invitrogen; Thermo Fisher Scientific, Inc.) was used for total RNA extraction from all types of cells according to standard procedures. The detection of EphA2 was performed via RT-qPCR using a high-capacity cDNA Reverse Transcription kit (Qiagen AB) and SYBR Premix Ex Taq (Qiagen $\mathrm{AB}$ ). The conditions for cDNA synthesis were as follows: $42^{\circ} \mathrm{C}$ for $30 \mathrm{~min}$ and $85^{\circ} \mathrm{C}$ for $5 \mathrm{sec}$. The thermocycling conditions were as follows: $95^{\circ} \mathrm{C}$ for $3 \mathrm{~min} ; 39$ cycles of $95^{\circ} \mathrm{C}$ for $5 \mathrm{sec}, 56^{\circ} \mathrm{C}$ for $10 \mathrm{sec}, 72^{\circ} \mathrm{C}$ for $25 \mathrm{sec} ; 65^{\circ} \mathrm{C}$ for $5 \mathrm{sec} ; 95^{\circ} \mathrm{C}$ for $50 \mathrm{sec}$. The relative expression levels were normalized to endogenous control GAPDH and were expressed as $2^{-\triangle \Delta C q}(22)$. The sequences of the primers were as follows: EphA2 forward, 5'-CTGGTCTGCAAGGTGTCTGA-3' and reverse, 5'-TTG GACAACTCCCAGTAGGG-3'; and GADPH forward, 5'-GAT ATTGTTGCCATCAATGAC-3' and reverse 5'-TTGATTTTG GAGGGATCTCG-3'.

Western blotting. All types of cells were separately lysed using RIPA lysis buffer (Sigma-Aldrich; Merck KGaA) and protein concentration was determined using the BCA method (Beyotime Institute of Biotechnology). Proteins (20 $\mu \mathrm{g} / \mathrm{lane})$ were separated by $10 \%$ SDS-PAGE and transferred onto PVDF membranes (MilliporeSigma). Membranes were blocked in $5 \%$ milk for $2 \mathrm{~h}$ at room temperature. The membranes were incubated at $4^{\circ} \mathrm{C}$ overnight with primary antibodies against EphA2 (cat. no. ab185156; 1:1,000; Abcam), GTP-RhoA (cat. no. 211164; 1:500; Abcam), ROCK1 (cat. no. 07-1458; 1:500; MilliporeSigma), total-RhoA (cat. no. ABS620; 1:400; MilliporeSigma) and GAPDH (cat. no. ab181602; 1:10,000; Abcam). Next, membranes were incubated with secondary anti-rabbit (cat. no. ab6721; 1:2,000; Abcam) or anti-mouse (cat. no. ab6728; 1:2,000; Abcam) antibodies at room temperature for $40 \mathrm{~min}$. Enhanced chemiluminescence reagent (Pierce; Thermo Fisher Scientific, Inc.) was used to detect the signal on the membrane. The data were analyzed via densitometry using Image $\mathrm{Lab}^{\mathrm{TM}}$ version 3.0 software (Bio-Rad Laboratories, Inc.) and normalized to expression of the internal control (GAPDH).

MTT assay. CaSki and HeLa cells were harvested, seeded in 96-well plates $\left(1 \times 10^{3}\right.$ cells $/ \mathrm{ml}$ per well) and grown until $80 \%$ confluence. MTT solution (5 mg/ml; Sigma-Aldrich; Merck $\mathrm{KGaA})$ was subsequently added to the cells $(15 \mu \mathrm{l} /$ well). Following $4 \mathrm{~h}$ of incubation of the cells with MTT solution at $37^{\circ} \mathrm{C}$, DMSO was added $(150 \mu \mathrm{l} /$ well $)$ to dissolve the formazan crystals. A microplate reader (Omega Bio-Tek, Inc.) was used for spectrophotometry-based measurements of the optical density at $490 \mathrm{~nm}$.

Colonyformationassay. CaSki and HeLacells $\left(7 \times 10^{2}\right.$ cells/well $)$ were seeded in a 6-well plate and cultured for 14 days to allow the formation of cell colonies. Following 14 days, the colonies were fixed with $10 \%$ formaldehyde for $30 \mathrm{~min}$ at room temperature and stained with $0.5 \%$ crystal violet for $5 \mathrm{~min}$ at room temperature. The images of the colonies ( $>50$ cells) were obtained using a camera (Olympus Corporation) and counted manually.

Transwell assay. Transwell upper chambers (pore size, $8.0 \mu \mathrm{m}$; BD Biosciences) were precoated with Matrigel. A 
total of $100 \mu \mathrm{l} \mathrm{CaSki}$ and HeLa cell suspension (1x10 ${ }^{5}$ cells) in serum-free medium was separately added into the upper chamber. The lower chamber was filled with RPMI-1640 medium supplemented with $10 \%$ FBS. Following $20 \mathrm{~h}$ of incubation, non-invasive cells in the upper chamber were removed and cells that had invaded the lower chamber were stained using Giemsa solution at room temperature for $15 \mathrm{~min}$. The number of invading cells was estimated using a light microscope (magnification, x 100) and quantified using ImageJ version 1.8.0 software (National Institutes of Health). The relative invasion rate was calculated as follows: Number of invasive cells/number of inoculated cells x $100 \%$. All procedures were repeated three times.

Wound healing assay. HeLa and CaSki cells (1x10 6 cells/well) were separately seeded in 6-well plates (Corning, Inc.) and cultured until they reached $95 \%$ confluence. The cell monolayer was slowly scratched with a sterile $200-\mu 1$ tip. Cellular debris was washed off with fresh medium and the remaining cells were cultured in serum-free RPMI-1640 medium accordingly. The images of the wound healing process were obtained at 0 and $24 \mathrm{~h}$ using a light microscope (magnification, $\mathrm{x} 100$ ). The area of wound was quantified using ImageJ version 1.8.0 software (National Institutes of Health). All procedures were repeated three times.

Bioinformatics analysis. The Gene Expression Profiling Interactive Analysis (GEPIA; http://gepia.cancer-pku.cn/) database is a website that provides the RNA sequencing expression data of 9,736 tumors and 8,587 normal samples from The Cancer Genome Atlas (TCGA) and the Genotype-Tissue Expression (GTEx) projects (23). This database was used to determine the expression difference of EphA2 between patients with cervical squamous cell carcinoma and endocervical adenocarcinoma (CESC) and healthy controls. A total of 306 tumor samples and 13 normal samples were obtained from GEPIA, with $\mid \log _{2} \mathrm{FCl}>1$ and $\mathrm{P}<0.01$ as the cutoff; where FC is fold-change. The UALCAN (http://ualcan.path.uab. $\mathrm{edu} /$ ) database is a portal for tumor subgroup gene expression and survival analyses, which provides data from TCGA, Clinical Proteomic Tumor Analysis Consortium (CPTAC) and The Children Brain Tumor Tissue Consortium(CBTTC) (24). This database was also used to determine the expression difference of EphA2 in patients with cervical squamous cell carcinoma and healthy controls. A total of 305 tumor samples and 3 normal samples were obtained from UALCAN. The analysis results are presented in the form of box plots.

Statistical analysis. The data are presented as the mean \pm standard deviation and were analyzed using GraphPad Prism version 8.0 (GraphPad Software, Inc.). One-way ANOVA followed by Tukey's post hoc test was used for data comparisons between multiple groups. $\mathrm{P}<0.05$ was considered to indicate a statistically significant difference. All experiments were performed at least three times.

\section{Results}

EphA2 expression is increased in CC cells. The result from GEPIA database analysis demonstrated that the expression level of EphA2 in 306 patients with cervical squamous cell carcinoma and endocervical adenocarcinoma was significantly higher than that in 13 normal samples (Fig. 1A). The boxplot from the UALCAN database of 305 patients and 3 normal samples also demonstrated the higher expression of EphA2 in primary tumor samples compared with that in normal samples (Fig. 1B). Subsequently, RT-qPCR and western blotting were used to determine EphA2 expression in HPV-positive CC cell lines (CaSki and HeLa), in the HPV-negative CC cell line (C33A) and in immortalized human cervical squamous cells (Ect1/E6E7). The results indicated that EphA2 expression levels were significantly higher in C33A, CaSki and HeLa cells than those noted in Ect1/E6E7 cells. The upward trends in CaSki and HeLa cells were more obvious compared with that in C33A cells (Fig. 1C and D). Therefore, CaSki and HeLa cells were selected for the subsequent assays.

ALW-II-41-27 inhibits the proliferation of CC cells. To investigate the effects of ALW-II-41-27 on the progression of CC, the proliferative capacity of CaSki and HeLa cells was determined prior to and following treatment with different concentrations of ALW-II-41-27. The results from an MTT assay demonstrated that ALW-II-41-27 significantly decreased the proliferative capacity of CaSki and HeLa cells, especially when cells were treated for 48 and $72 \mathrm{~h}$ with 1,000 nM ALW-II-41-27 (Fig. 2A and B). In addition, the number of colonies of both CaSki and HeLa cells was significantly decreased following treatment with different concentrations of ALW-II-41-27 (Fig. 2C and D). In particular, the concentration of 1,000 nM exerted the most prominent inhibitory effect on cell colony formation (Fig. 2C and D). These results demonstrated that ALW-II-41-27 could inhibit CC cell proliferation.

ALW-II-41-27 inhibits the migration and invasion of CC cells. CC cell migration and invasion were detected prior to and following treatment with different concentrations of ALW-II-41-27. The results from the wound-healing assay indicated that ALW-II-41-27 significantly inhibited CaSki and HeLa cell migration (Fig. 3A and C). Furthermore, ALW-II-41-27 significantly inhibited CaSki and HeLa cell invasive activity (Fig. 3B and D). These findings also indicated a concentration-dependent inhibition of CC cell progression by ALW-II-41-27, with 1,000 nM ALW-II-41-27 exerting the most significant inhibitory effects. These findings indicated the inhibitory effect of ALW-II-41-27 on CC cell migration and invasion.

ALW-II-41-27 inhibits the RhoA/ROCK pathway in CC cells. It has been reported that overexpression of ROCK-I/II is associated with the progression of CC (19). A previous study confirmed that RhoA can promote the proliferation and migration of CC cells (19). These results indicate that ALW-II-41-27 suppresses the malignant activity of $\mathrm{CC}$ cells. A potential regulatory association between ALW-II-41-27 and the RhoA/ROCK pathway was therefore hypothesized. In the present study, western blotting analysis was performed to determine the expression of the proteins associated with the RhoA/ROCK pathway. The results indicated that the protein expression of GTP-RhoA and ROCK1 was significantly decreased by different concentrations of ALW-II-41-27 in 
A

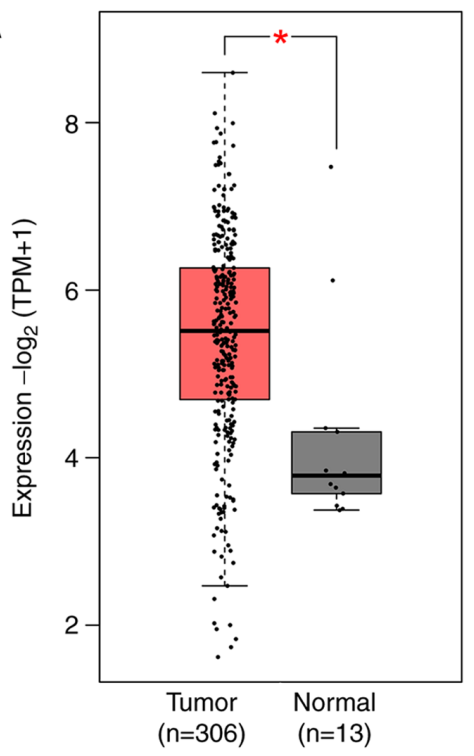

C

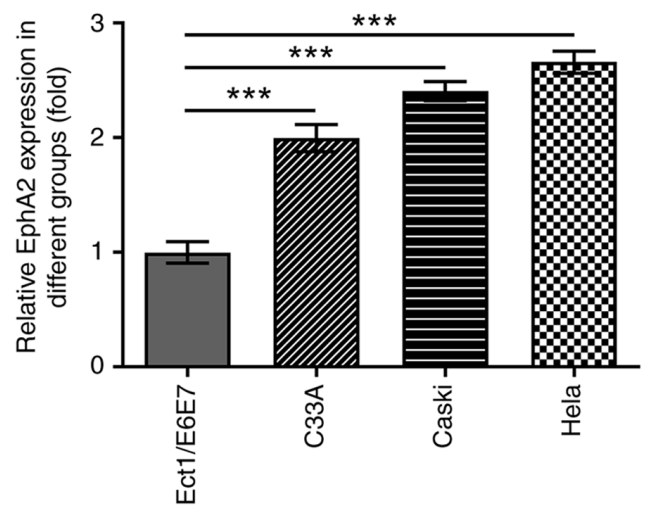

B

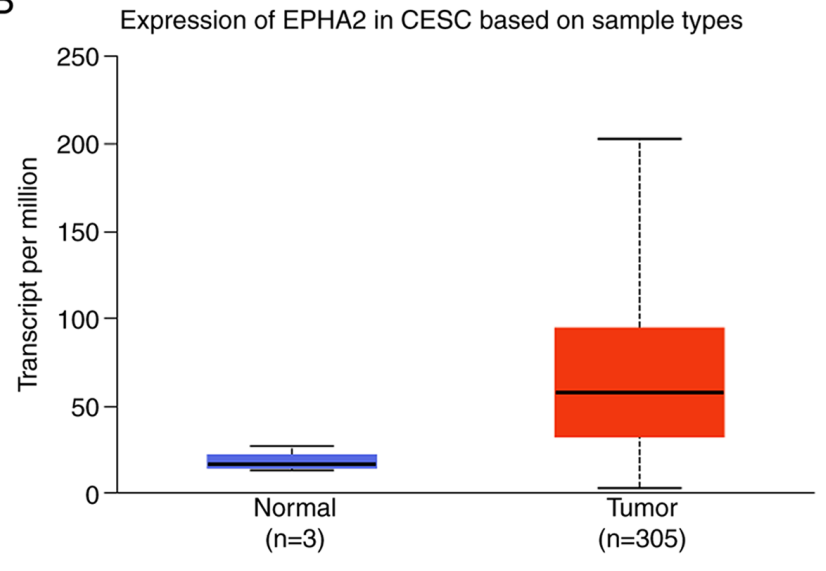

D

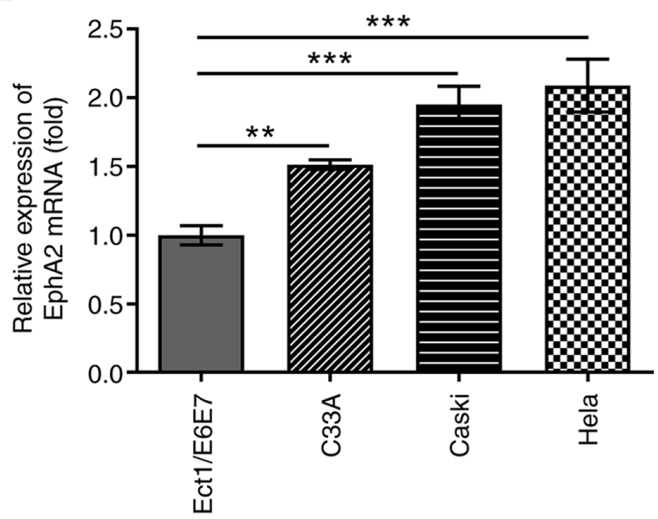

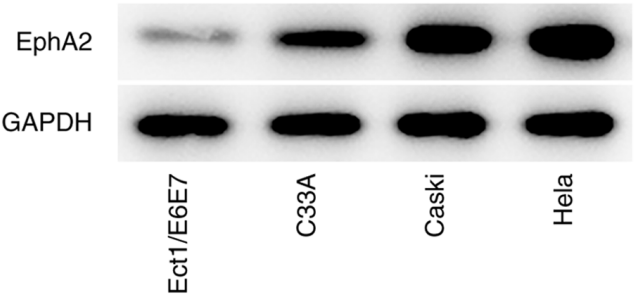

Figure 1. EphA2 expression is upregulated in cervical cancer cells. EphA2 expression in CESC and normal samples was examined using the (A) Gene Expression Profiling Interactive Analysis and (B) UALCAN databases. EphA2 expression was detected using (C) reverse transcription quantitative PCR and (D) western blotting. ${ }^{*} \mathrm{P}<0.05,{ }^{* *} \mathrm{P}<0.01$ and ${ }^{* * * *} \mathrm{P}<0.001$. EphA2, Eph receptor A2; CESC, cervical squamous cell carcinoma and endocervical adenocarcinoma; TCGA, The Cancer Genome Atlas.

CaSki and HeLa cells, whereas the total protein expression of RhoA was unchanged (Fig. 4A and B). In addition, ALW-II-41-27 at the concentration of 1,000 $\mathrm{nM}$ caused the highest downregulations of GTP-RhoA and ROCK.

ALW-II-41-27 inhibits the proliferation, invasion and migration of CC cells by blocking the RhoA/ROCK pathway. To explore whether ALW-II-41-27 could suppress CC cell progression via the RhoA/ROCK pathway, CaSki and HeLa cells were co-treated with ALW-II-41-27 and PMA in the absence or presence of C3 transferase or hydroxyfasudil. Since ALW-II-41-27 functioned in a concentration-dependent manner, the most efficient concentration of $1,000 \mathrm{nM}$ was selected for the following assays. The results from western blotting indicated that GTP-RhoA and ROCK1 protein expression was decreased following treatment with ALW-II-41-27 compared with that in the control group, while the addition of PMA largely reversed this change (Fig. 5A and B). Co-treatment of the cells with C3 transferase or hydroxyfasudil further decreased the expression of GTP-RhoA and ROCK compared with the expression following treatment with PMA + ALW-II-41-27, whereas that of total-RhoA level remained the same (Fig. 5A and B).

The results from the MTT assay revealed that ALW-II-41-27 significantly decreased CC cell proliferation compared with the control and that PMA hindered its effect. Co-treatment with PMA and C3 transferase or hydroxyfasudil significantly 


\section{A}
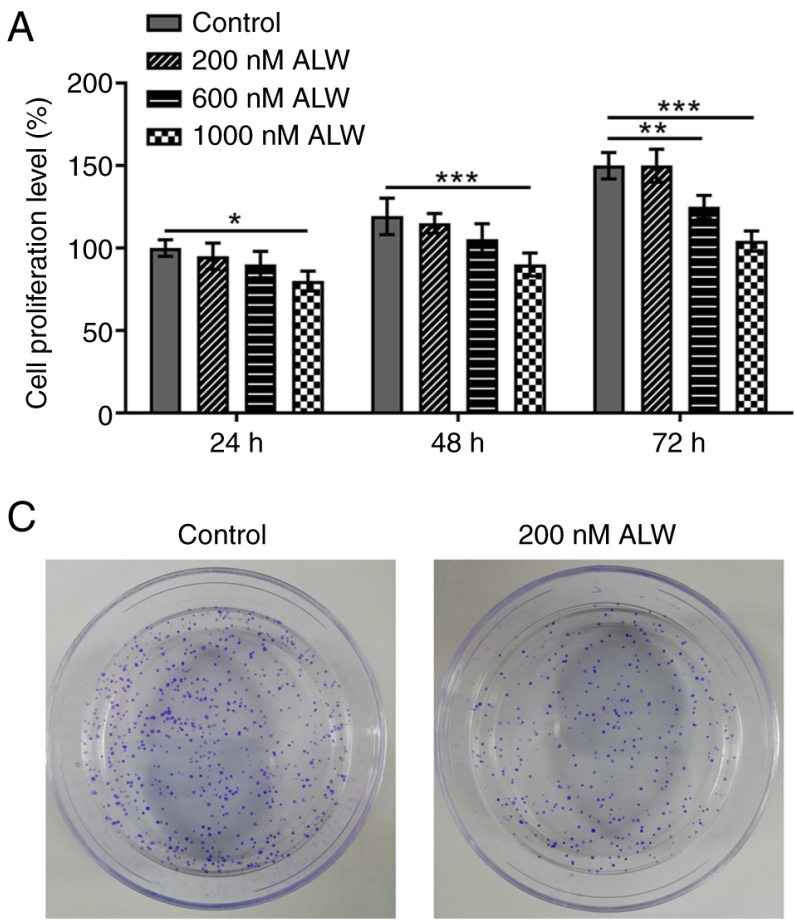

600 nM ALW
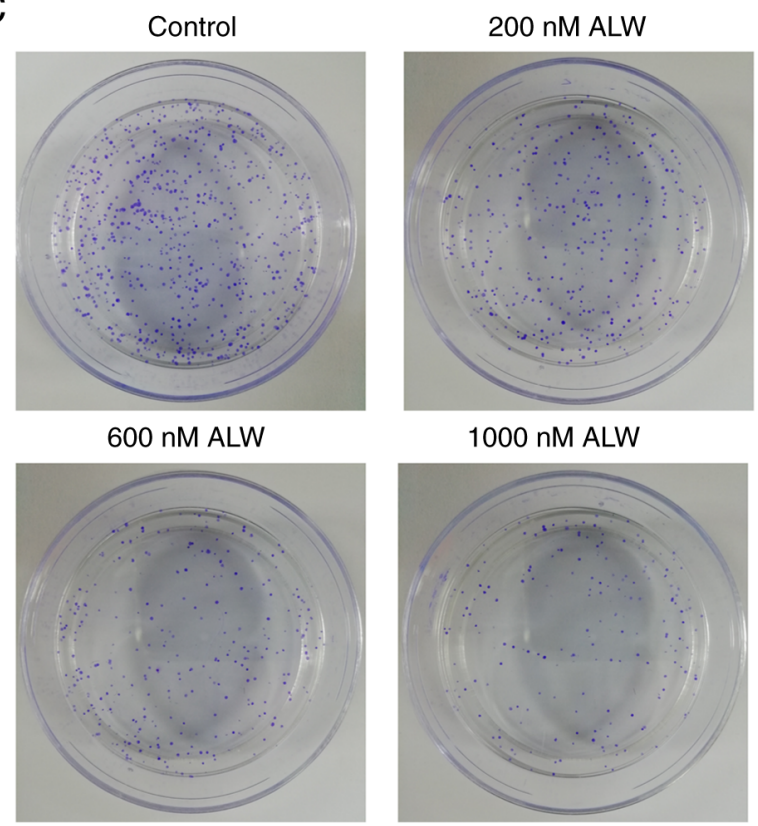

$1000 \mathrm{nM}$ ALW
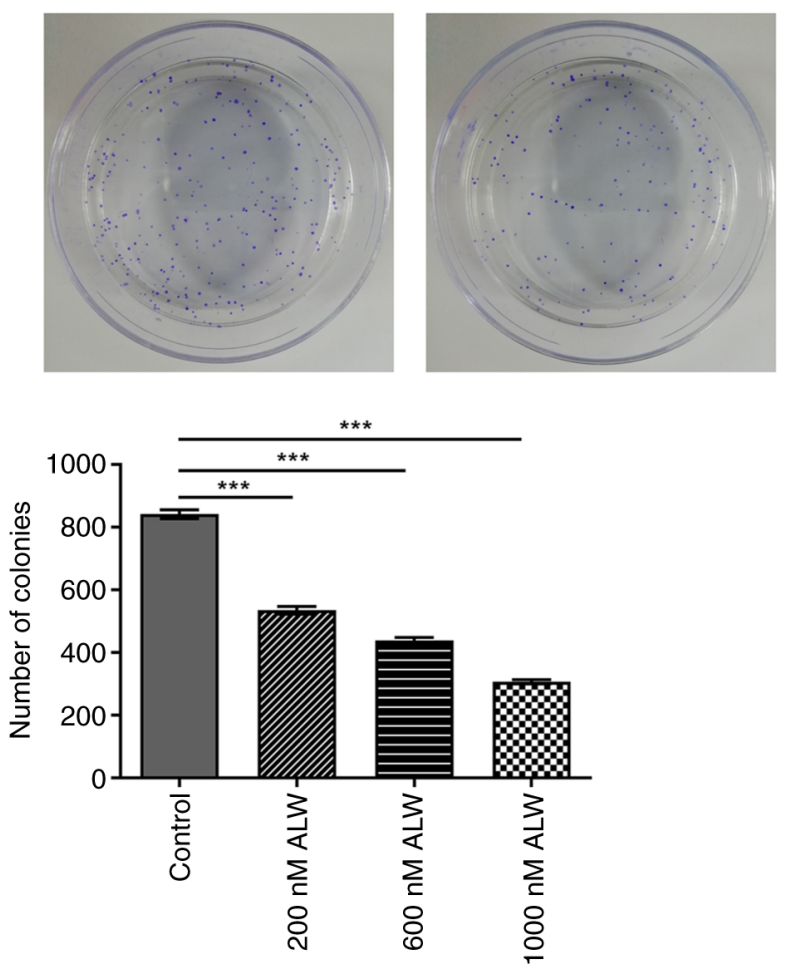
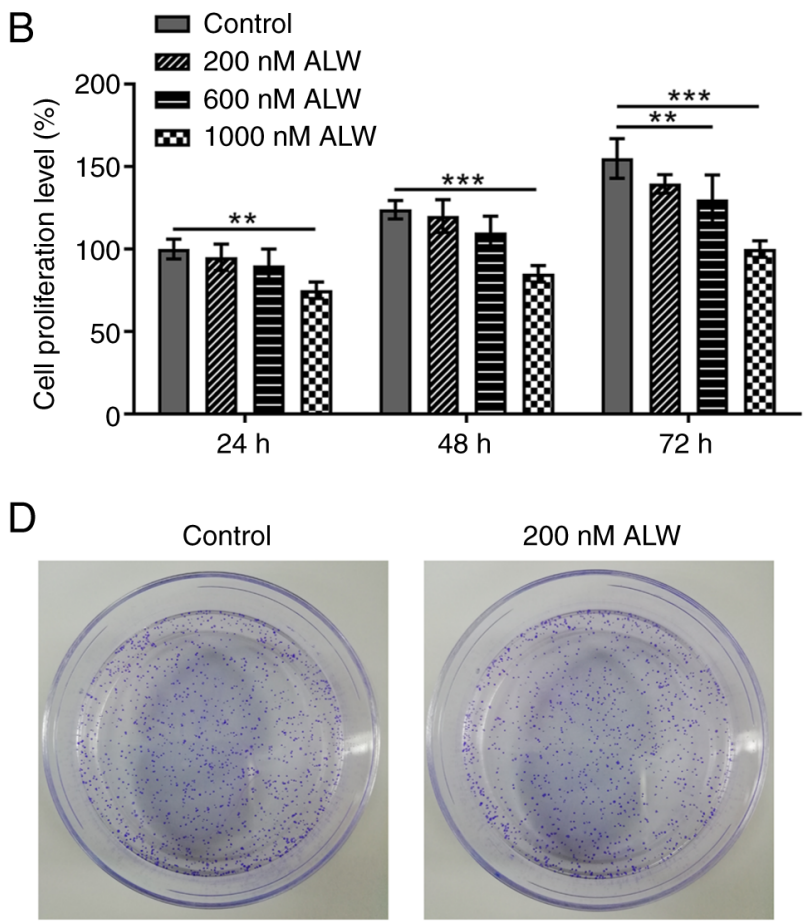

$600 \mathrm{nM}$ ALW
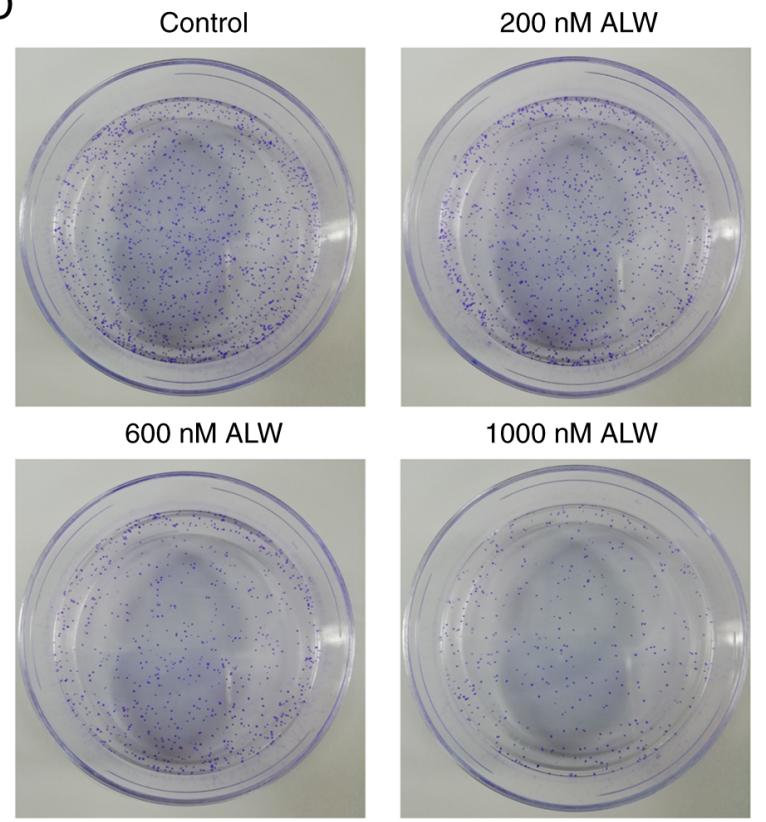

1000 nM ALW
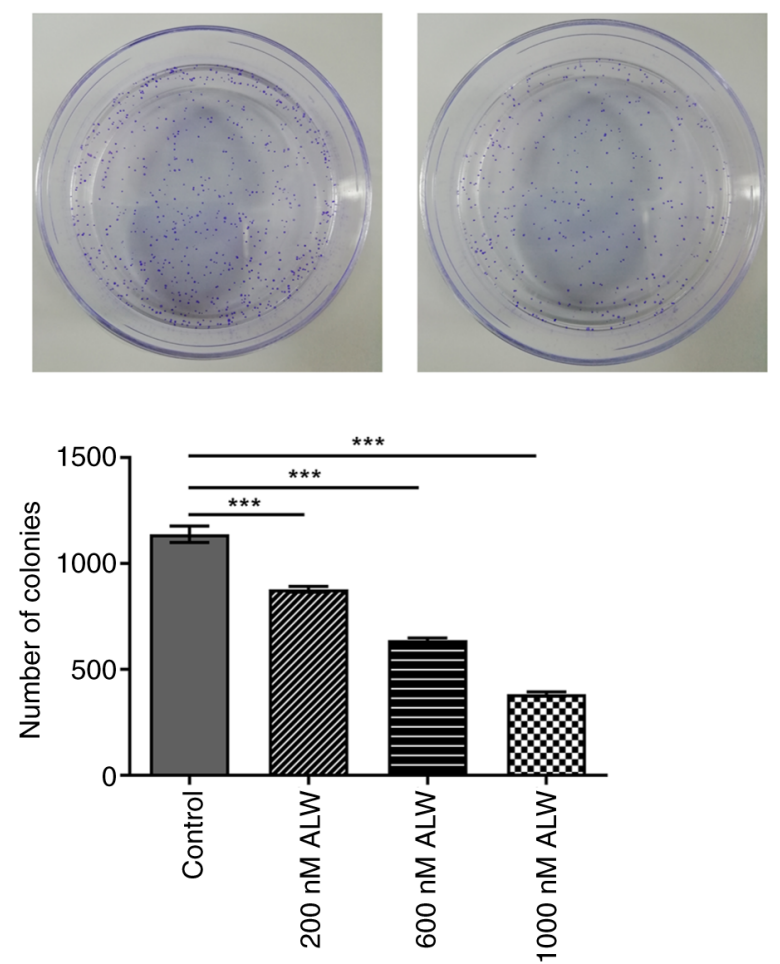

Figure 2. ALW-II-41-27 inhibits the proliferation of CaSki and HeLa cell lines. Proliferative activity was detected using the MTT assay in (A) CaSki and (B) HeLa cells treated with different concentrations of ALW-II-41-27 (200, 600 and 1,000 nM). Proliferative activity was detected using the colony formation assay in (C) CaSki and (D) HeLa cells treated with different concentrations of ALW-II-41-27. ${ }^{*} \mathrm{P}<0.05,{ }^{* * *} \mathrm{P}<0.01$ and ${ }^{* * * *} \mathrm{P}<0.001$. ALW, ALW-II-41-27.

decreased ALW-II-41-27 + PMA-promoted cell proliferation at $72 \mathrm{~h}$. CaSki and HeLa cells presented similar trends (Fig. 5C and D). The results of the colony formation assay indicated that co-treatment with PMA and C3 transferase or hydroxyfasudil inhibited cell colony formation, which was consistent with the results of the MTT assay (Fig. 5E and F).

The results from the wound healing and Transwell assays revealed that ALW-II-41-27-treated CaSki and HeLa cells exhibited lower migratory and invasive activities compared with the control, while activities were partially restored in the PMA and ALW-II-41-27 co-treatment groups. The migratory activities of ALW-II-41-27-treated CC cells detected by wound healing assays were decreased following co-treatment with PMA and C3 transferase or hydroxyfasudil (Fig. 6A and C). The results of invasive activities from the Transwell assays presented similar trends among the different groups 
A
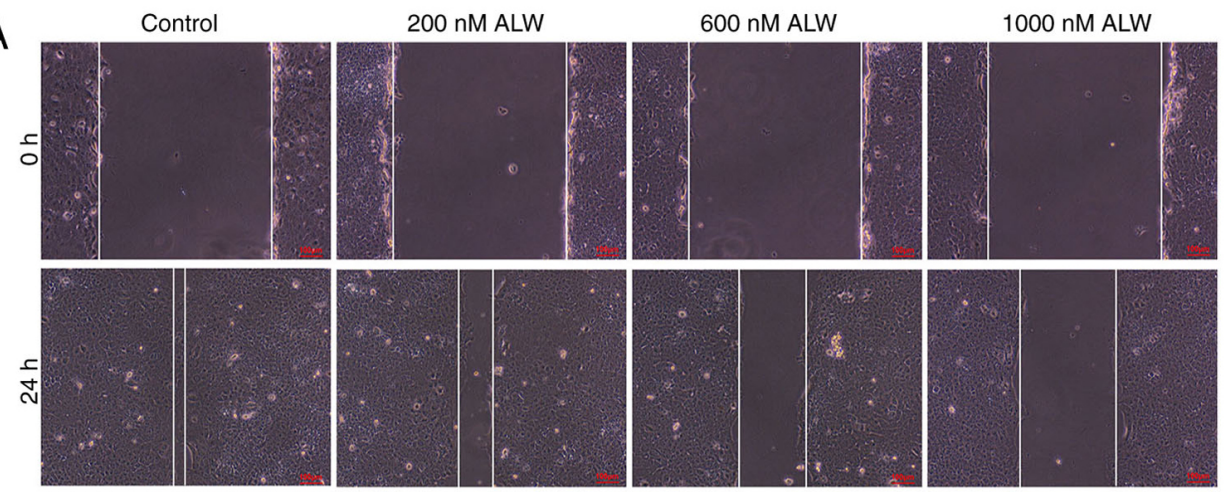

B

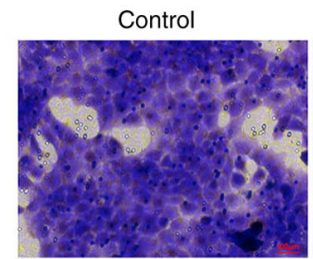

200 nM ALW

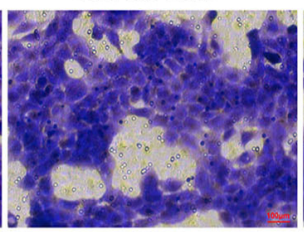

600 nM ALW

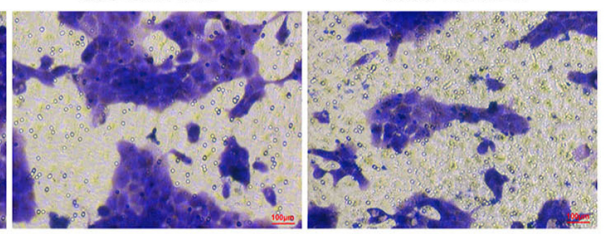

C

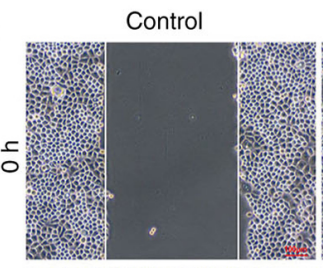

$200 \mathrm{nM}$ ALW

$600 \mathrm{nM}$ ALW

1000 nM ALW
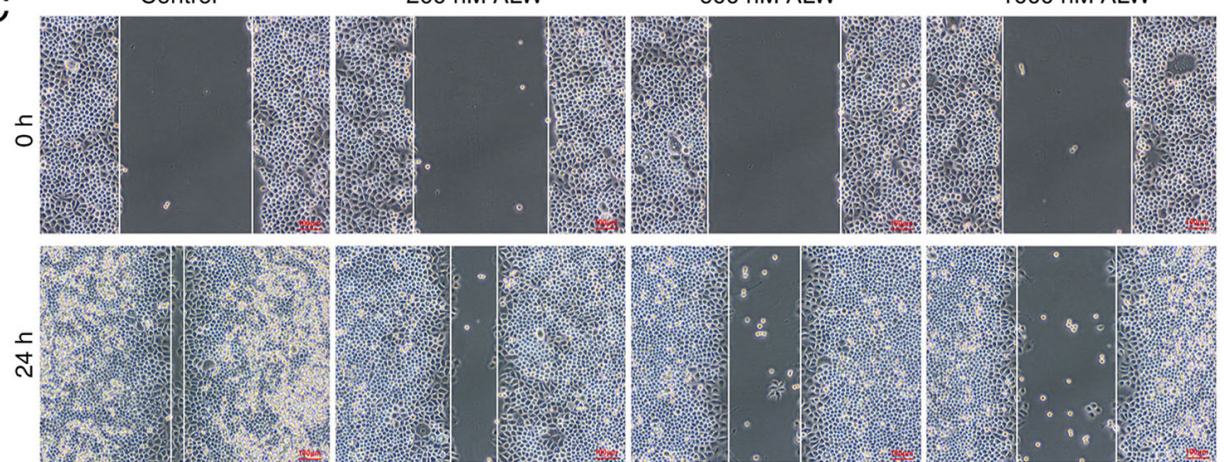

D

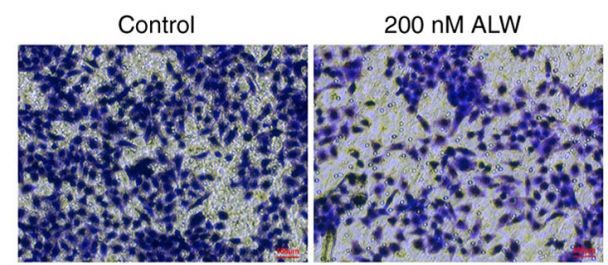

600 nM ALW
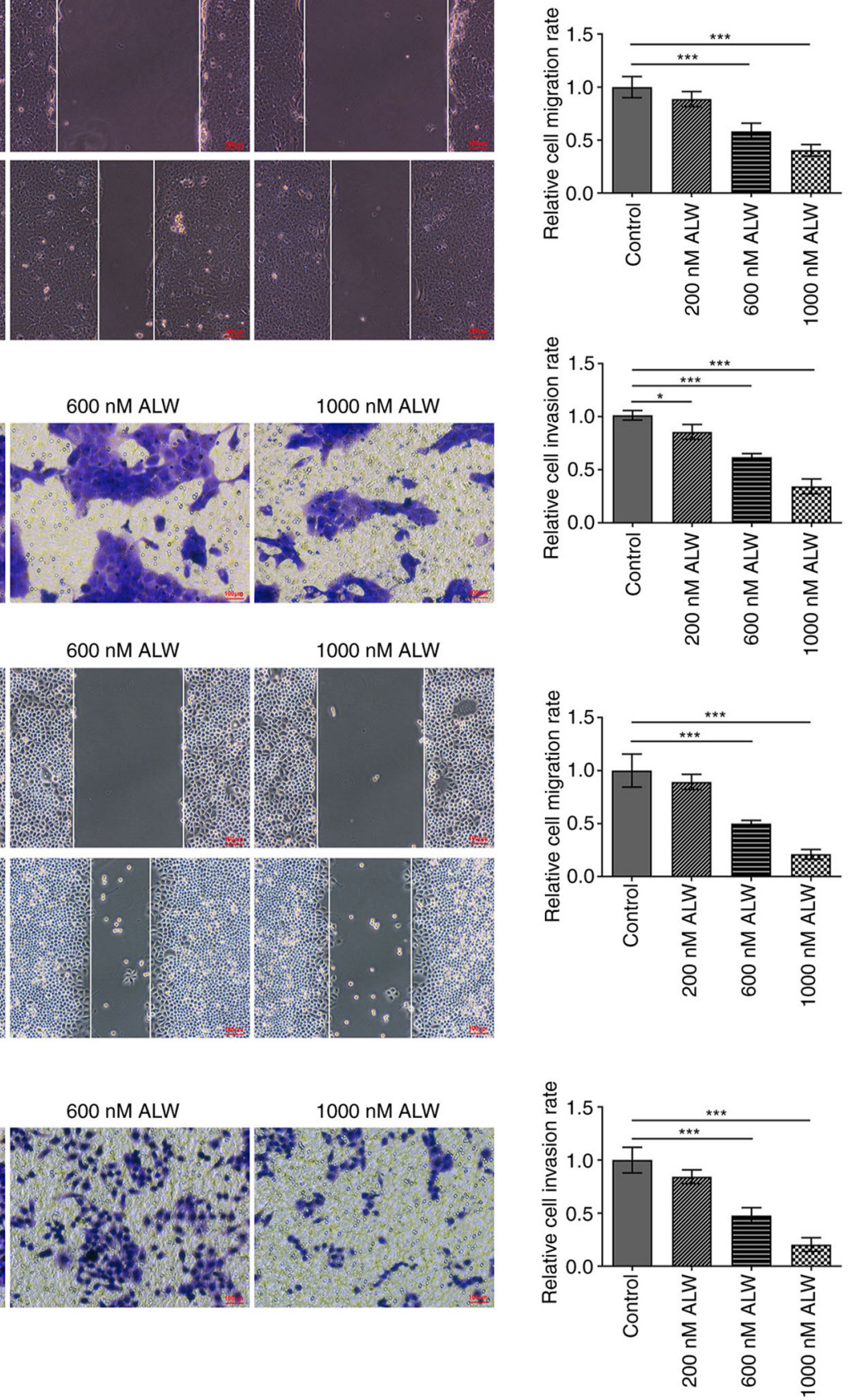

Figure 3. ALW-II-41-27 inhibits the migration and invasion of CaSki and HeLa cell lines. (A) Wound healing and (B) Transwell assays were used to assess the migratory and invasive activities of CaSki cells treated with different concentrations of ALW-II-41-27 (200, 600 and 1,000 nM). (C) Wound healing and (D) Transwell assays were used to assess the migratory and invasive activities of HeLa cells treated with different concentrations of ALW-II-41-27 (200, 600 and $1,000 \mathrm{nM})$. Magnification, $\mathrm{x} 100 .{ }^{*} \mathrm{P}<0.05$ and ${ }^{* * *} \mathrm{P}<0.001$. ALW, ALW-II-41-27.

(Fig. 6B and D). These findings indicated that ALW-II-41-27 could suppress the malignant activity of $\mathrm{CC}$ cells by blocking the RhoA/ROCK signaling pathway.

\section{Discussion}

$\mathrm{CC}$ ranks fourth among the most lethal gynecological malignancies worldwide (25). Despite the efforts made to improve the efficacy of standard treatment for $\mathrm{CC}$, including surgical excision assisted by chemotherapy and radiotherapy $(26,27)$, the 5-year overall survival rate remains low in metastatic cases (28). Therefore, in-depth exploration and understanding of the pathogenesis and developmental process of $\mathrm{CC}$ are crucial for the development of novel therapeutic drugs and the search for novel treatment strategies.

EphA2 is expressed at high levels in several human tumors, such as prostate, bladder, skin and lung tumors (29). Furthermore, cancer cells of the highest tumor stage exhibit the highest expression levels of EphA2 (30). In addition, a previous study demonstrated that EphA2 overexpression was closely associated with a poor prognosis, a higher probability of metastasis and a shorter overall survival time in Ewing 

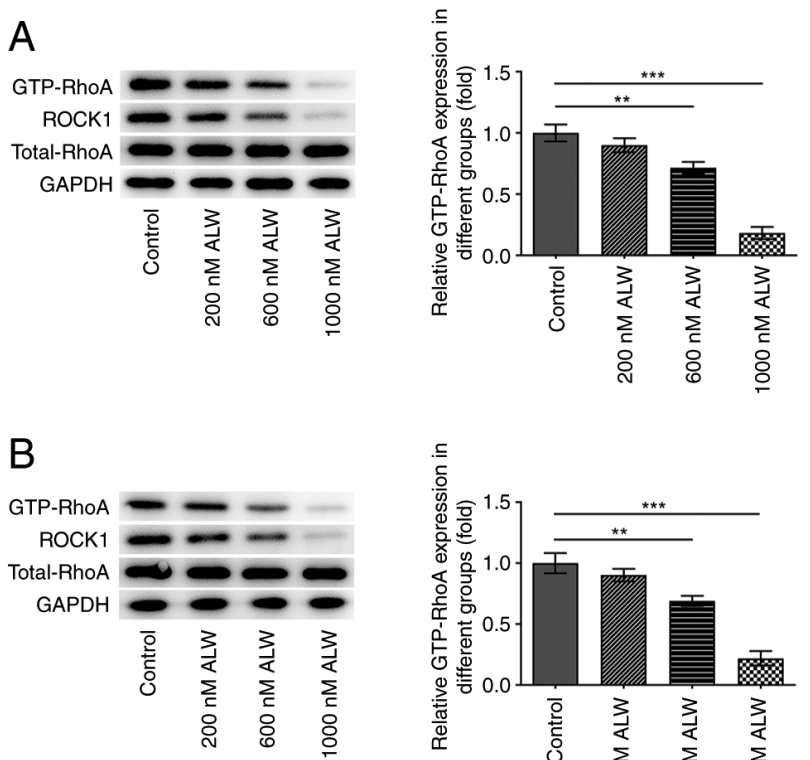

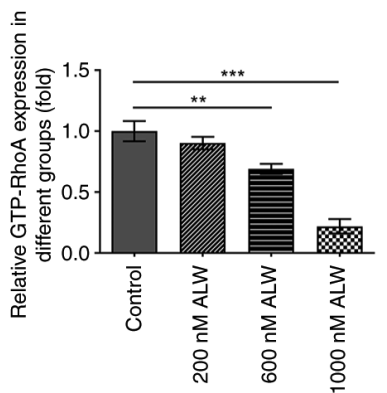

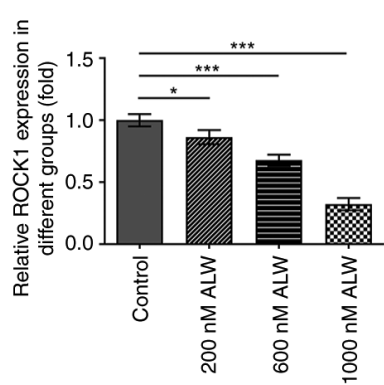
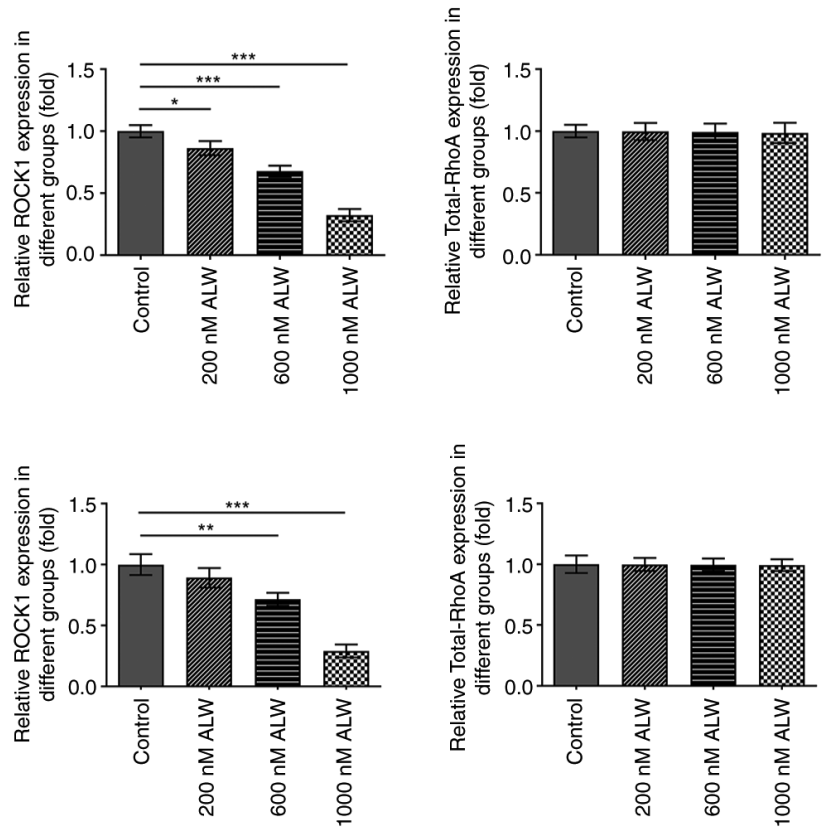

Figure 4. ALW-II-41-27 inhibits the expression levels of GTP-RhoA and ROCK1 in CaSki and HeLa cells. The expression levels of GTP-RhoA, ROCK1 and total-RhoA were determined via western blotting and RT-qPCR analyses in (A) CaSki and (B) HeLa cells following treatment with different concentrations of ALW-II-41-27 (200, 600 and 1,000 nM). ${ }^{*} \mathrm{P}<0.05,{ }^{* *} \mathrm{P}<0.01$ and ${ }^{* * *} \mathrm{P}<0.001$. RhoA, Ras homolog family member A; ROCK1, Rho-associated protein kinase; RT-qPCR, reverse transcription quantitative PCR; ALW, ALW-II-41-27.

sarcoma (31). Furthermore, EphA2 plays a novel role in atherosclerosis, regulating both plaque inflammation and progression to advanced atherosclerotic lesions (32). EphA2 might also serve as a novel target for bladder cancer therapy (33). In addition, high expression of EphA2 together with EphrinA-1 is negatively correlated with the overall survival and prognosis of squamous cell CC (12). In the present study, EphA2 expression levels were assessed by western blotting and RT-qPCR analyses in CC cell lines. A significant increase in EphA2 expression was demonstrated in both HPV-positive CC cell lines and the HPV-negative CC cell line. Therefore, CaSki and HeLa cell lines were selected for subsequent experiments in the present study. To evaluate the function of EphA2 in the progression of CC cells, the EphA2 inhibitor ALW-II-41-27 was used to treat the CaSki and HeLa cell lines. The results from MTT and colony formation assays indicated that ALW-II-41-27 decreased the proliferative activity of the CaSki and HeLa cells in a concentration-dependent manner. Subsequently, Transwell and wound-healing assays were performed. The results demonstrated that ALW-II-41-27 could also inhibit the migratory and invasive activities of CaSki and HeLa cells, and that 1,000 nM ALW-II-41-27 exhibited an optimal inhibitory effect.

Investigation of the molecularmechanism of ALW-II-41-27 in inhibiting the growth and metastasis of $\mathrm{CC}$ was focused on its potential to regulate the RhoA/ROCK pathway. A previous study reported that the RhoA/ROCK pathway could mediate cardiomyocyte apoptosis via induction of oxidative stress and activation of the p38 MAPK and JNK pathways in vitro. These experiments were performed in primary cardiomyocytes isolated from ventricles of neonatal rats (34). In addition, it has been demonstrated that Shroom family member 2 inhibits tumor metastasis via the RhoA/ROCK pathway in nasopharyngeal carcinoma (35). Targeting the RhoA/ROCK signaling pathway is also considered as an effective method to suppress breast cancer progression and lung cancer metastasis (36). Furthermore, a previous study reported that vascular endothelial growth factor- $\mathrm{C}$ facilitates CC metastasis via RhoA/ROCK-2-regulated activation of the moesin protein (37). Quercetin can induce apoptosis and loss of proliferation, migration and angiogenesis of $\mathrm{SiHa} \mathrm{CC}$ cells by downregulating the expression levels of specific tumor-regulating genes, such as Akt1, Bcl-2-like 1, cyclin D1 gene, cyclin-dependent kinase 4, Polo-like kinase 1 and RhoA (38). In the present study, the protein expression of GTP-RhoA and ROCK1 was downregulated in a concentration-dependent manner following ALW-II-41-27 treatment, whereas the expression of total-RhoA did not change. Furthermore, to investigate the involvement of the RhoA/ROCK pathway in the effects of ALW-II-41-27 on CC cell progression, the RhoA/ROCK pathway agonist PMA, the RhoA inhibitor C3 transferase and the ROCK blocker hydroxyfasudil were used. Although PMA restored ALW-II-41-27-mediated inhibition of CC cell proliferation, migration and invasion, both $\mathrm{C} 3$ transferase and hydroxyfasudi could reverse the changes caused by PMA treatment. These results indicated that ALW-II-41-27 could inhibit $\mathrm{CC}$ cell proliferation, migration and invasion by inhibiting the RhoA/ROCK pathway. It is notable that the ROCK inhibitor Y-27632 has been shown to induce upregulation of p63 expression in CC cells (39). This protein is considered to play a fundamental role in cancer types arising from multi-layered epithelium, for example, p63 participates in the malignant phenotypes of esophageal squamous cell cancer cells $(40,41)$. In addition, a previous study demonstrated that ROCK kinase could impede p63 nuclear transport in 

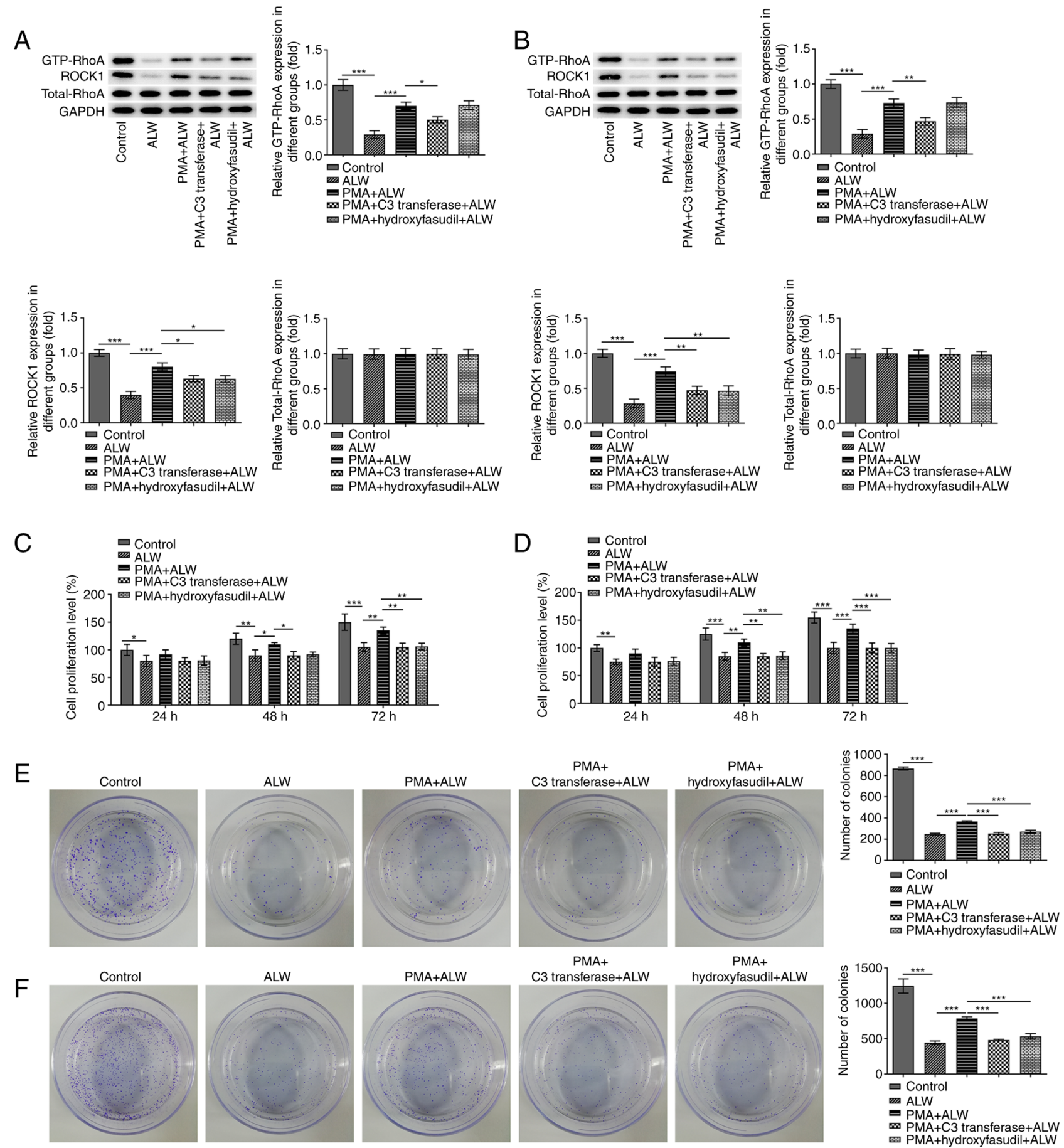

Figure 5. ALW-II-41-27 inhibits the proliferative, invasive and migratory activities of cervical cancer cells by blocking the RhoA/ROCK pathway. Expression levels of GTP-RhoA, ROCK1 and total-RhoA were determined by western blotting and reverse transcription quantitative PCR analyses in (A) CaSki and (B) HeLa cells treated with ALW-II-41-27, ALW-II-41-27 (1,000 nM) + PMA (100 ng/ml), ALW-II-41-27 + PMA + C3 transferase (5 $\mu \mathrm{g} / \mathrm{ml})$ or hydroxyfasudil $(10 \mu \mathrm{M})$. The proliferation of (C) CaSki and (D) HeLa cells was assessed using the MTT assay. The proliferation of (E) CaSki and (F) HeLa cells was assessed using a colony formation assay. ${ }^{*} \mathrm{P}<0.05,{ }^{* *} \mathrm{P}<0.01$ and ${ }^{* * *} \mathrm{P}<0.001$. RhoA, Ras homolog family member A; ROCK1, Rho-associated protein kinase; PMA, phorbol 12-myristate 13-acetate; ALW, ALW-II-41-27.

squamous cell carcinoma (42). The results from these two studies are fairly different compared with those from the aforementioned studies, as well as with the findings from the present study, suggesting that additional investigation is required to determine the exact underlying mechanism of ALW-II-41-27.

In summary, the present study demonstrated that EphA2 was expressed at abnormally high levels in CC cells.
Downregulation of EphA2 expression levels was induced following CC cell treatment with the inhibitor ALW-II-41-27, resulting in decreased cell proliferation, migration and invasion. ALW-II-41-27 may therefore impact the aforementioned aspects of $\mathrm{CC}$ cells, including proliferation, migration and invasion, by blocking the RhoA/ROCK pathway. The present study involved basic in vitro experiments. Additional in-depth mechanistic studies and in vivo experiments are therefore 

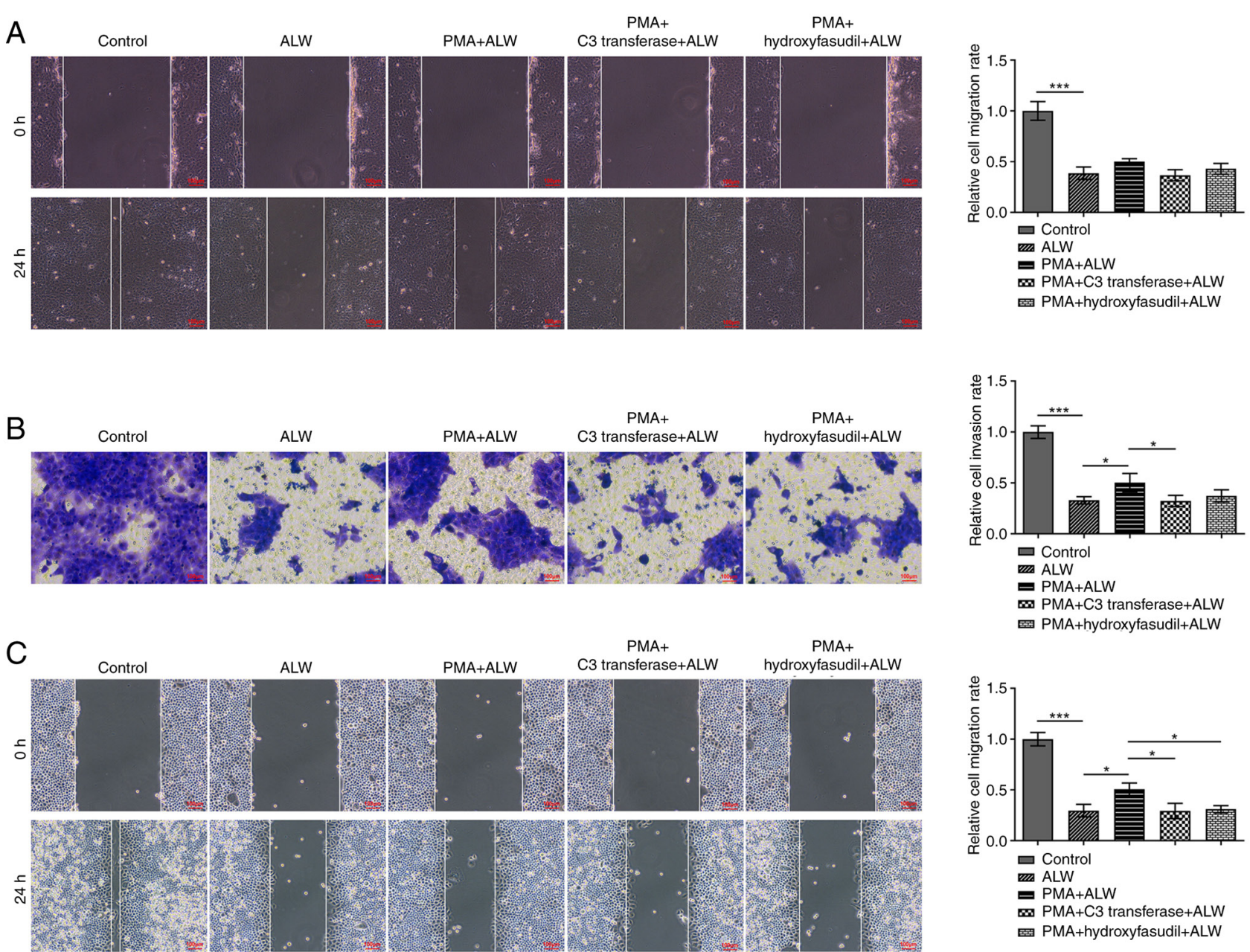

D
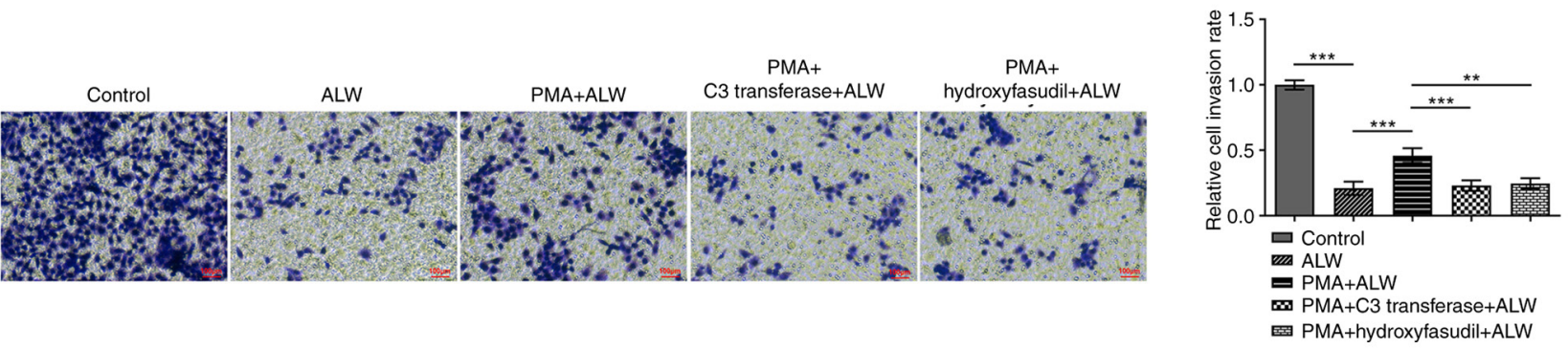

Figure 6. ALW-II-41-27 inhibits the proliferation, invasion and migration of cervical cancer cells by blocking the RhoA/ROCK pathway. (A) Transwell and (B) wound-healing assays were used to assess cell migratory and invasive activities of CaSki cells. (C) Transwell and (D) wound-healing assays were used to assess cell migratory and invasive activities of HeLa cells. Magnification, $x 100 .{ }^{*} \mathrm{P}<0.05,{ }^{* *} \mathrm{P}<0.01$ and ${ }^{* * *} \mathrm{P}<0.001$. RhoA, Ras homolog family member $\mathrm{A}$; ROCK1, Rho-associated protein kinase; PMA, phorbol 12-myristate 13-acetate; ALW, ALW-II-41-27.

required to confirm these findings. The present study explored the association between EphA2 and CC, and identified the crucial role of EphA2 in disease progression. Inhibition of EphA2 expression may thus be considered as a promising therapeutic strategy for the treatment or the control of CC. In addition, this study demonstrated that RhoA/ROCK may be a key pathway in the regulation of EphA2 and should therefore be examined further in the future to improve the understanding of CC pathogenesis.

\section{Acknowledgements}

Not applicable.

\section{Funding}

No funding was received.

\section{Availability of data and materials}

The datasets used and/or analyzed during the current study are available from the corresponding author on reasonable request.

\section{Authors' contributions}

$\mathrm{XL}$ and DL contributed equally to this work and made substantial contributions to conception and design, acquisition of data 
and analysis and interpretation of data. RM made substantial contributions to the conception and design of the study, and the analysis and interpretation of data, and was involved in drafting and critically revising the manuscript for important intellectual content. XL, DL and RM confirm the authenticity of the data, and have read and approved the final version of the manuscript.

\section{Ethics approval and consent to participate}

Not applicable.

\section{Patient consent for publication}

Not applicable.

\section{Competing interests}

The authors declare that they have no competing interests.

\section{References}

1. Pimple SA and Mishra GA: Global strategies for cervical cancer prevention and screening. Minerva Ginecol 71: 313-320, 2019.

2. Bray F, Ferlay J, Soerjomataram I, Siegel RL, Torre LA and Jemal A: Global cancer statistics 2018: GLOBOCAN estimates of incidence and mortality worldwide for 36 cancers in 185 countries. CA Cancer J Clin 68: 394-424, 2018.

3. Bhatla N and Singhal S: Primary HPV screening for cervical cancer. Best Pract Res Clin Obstet Gynaecol 65: 98-108, 2020.

4. Chen W, Zheng R, Baade PD, Zhang S, Zeng H, Bray F, Jemal A, Yu XQ and He J: Cancer statistics in China, 2015. CA Cancer J Clin 66: 115-132, 2016.

5. Stumbar SE, Stevens M and Feld Z: Cervical cancer and its precursors: A preventative approach to screening, diagnosis, and management. Prim Care 46: 117-134, 2019.

6. Sun Y, Yang X, Liu M and Tang H: Corrigendum to 'B4GALT3 up-regulation by miR-27a contributes to the oncogenic activity in human cervical cancer cells.' [Canc. Lett. 375 (2016) 284-292]. Cancer Lett 493: 16-18, 2020.

7. Zelinski DP, Zantek ND, Stewart JC, Irizarry AR and Kinch MS: EphA2 overexpression causes tumorigenesis of mammary epithelial cells. Cancer Res 61: 2301-2306, 2001.

8. Walker-Daniels J, Coffman K, Azimi M, Rhim JS, Bostwick DG, Snyder P, Kerns BJ, Waters DJ and Kinch MS: Overexpression of the EphA2 tyrosine kinase in prostate cancer. Prostate 41: 275-280, 1999.

9. Miyazaki T, Kato H, Fukuchi M, Nakajima M and Kuwano H: EphA2 overexpression correlates with poor prognosis in esophageal squamous cell carcinoma. Int J Cancer 103: 657-663, 2003.

10. Kinch MS, Moore MB and Harpole DH Jr: Predictive value of the EphA2 receptor tyrosine kinase in lung cancer recurrence and survival. Clin Cancer Res 9: 613-618, 2003.

11. Zeng G, Hu Z, Kinch MS, Pan CX, Flockhart DA, Kao C, Gardner TA, Zhang S, Li L, Baldridge LA, et al: High-level expression of EphA2 receptor tyrosine kinase in prostatic intraepithelial neoplasia. Am J Pathol 163: 2271-2276, 2003.

12. Wu D, Suo Z, Kristensen GB, Li S, Troen G, Holm R and Nesland JM: Prognostic value of EphA2 and EphrinA-1 in squamous cell cervical carcinoma. Gynecol Oncol 94: 312-319, 2004.

13. Zeng L, Li K, Wei H, Hu J, Jiao L, Yu S and Xiong Y: A novel EphA2 inhibitor exerts beneficial effects in PI-IBS in vivo and in vitro models via Nrf2 and NF- $\kappa \mathrm{B}$ signaling pathways. Front Pharmacol 9: 272, 2018.

14. Hong HN, Won YJ, Shim JH, Kim HJ, Han SH, Kim BS and Kim HS: Cancer-associated fibroblasts promote gastric tumorigenesis through EphA2 activation in a ligand-independent manner. J Cancer Res Clin Oncol 144: 1649-1663, 2018.

15. Ishigaki H, Minami T, Morimura O, Kitai H, Horio D, Koda $Y$, Fujimoto E, Negi Y, Nakajima Y, Niki M, et al: EphA2 inhibition suppresses proliferation of small-cell lung cancer cells through inducing cell cycle arrest. Biochem Biophys Res Commun 519: 846-853, 2019.
16. Feng G, Sun B, Liu HX, Liu QH, Zhao L and Wang TL: EphA2 antagonism alleviates LPS-induced acute lung injury via Nrf2/HO-1, TLR4/MyD88 and RhoA/ROCK pathways. Int Immunopharmacol 72: 176-185, 2019.

17. Yuan B, Cui J, Wang W and Deng K: G $\alpha 12 / 13$ signaling promotes cervical cancer invasion through the RhoA/ROCK-JNK signaling axis. Biochem Biophys Res Commun 473: 1240-1246, 2016.

18. Hou C, Zhuang Z, Deng X, Xu Y,Zhang P and Zhu L: Knockdown of Trio by CRISPR/Cas9 suppresses migration and invasion of cervical cancer cells. Oncol Rep 39: 795-801, 2018.

19. Liu X, Chen D and Liu G: Overexpression of RhoA promotes the proliferation and migration of cervical cancer cells. Biosci Biotechnol Biochem 78: 1895-1901, 2014.

20. Peng Q, Chen L, Wu W, Wang J, Zheng X, Chen Z, Jiang Q, Han J, Wei L, Wang L, et al: EPH receptor A2 governs a feedback loop that activates Wnt/ $\beta$-catenin signaling in gastric cancer. Cell Death Dis 9: 1146, 2018.

21. Xu XP, He HL, Hu SL, Han JB, Huang LL, Xu JY, Xie JF, Liu AR, Yang Y and Qiu HB: Ang II-AT2R increases mesenchymal stem cell migration by signaling through the FAK and RhoA/Cdc42 pathways in vitro. Stem Cell Res Ther 8: 164, 2017.

22. Livak KJ and Schmittgen TD: Analysis of relative gene expression data using real-time quantitative PCR and the 2(-Delta Delta C(T)) Method. Methods 25: 402-408, 2001.

23. Tang Z, Li C, Kang B, Gao G, Li C and Zhang Z: GEPIA: A web server for cancer and normal gene expression profiling and interactive analyses. Nucleic Acids Res 45(W1): W98-W102, 2017.

24. Chandrashekar DS, Bashel B, Balasubramanya SAH, Creighton CJ, Ponce-Rodriguez I, Chakravarthi BVSK and Varambally S: UALCAN: A portal for facilitating tumor subgroup gene expression and survival analyses. Neoplasia 19: 649-658, 2017.

25. Cancer Genome Atlas Research Network; Albert Einstein College of Medicine; Analytical Biological Services; Barretos Cancer Hospital; Baylor College of Medicine; Beckman Research Institute of City of Hope; Buck Institute for Research on Aging; Canada's Michael Smith Genome Sciences Centre; Harvard Medical School; Helen F, et al: Integrated genomic and molecular characterization of cervical cancer. Nature 543: 378-384, 2017.

26. Yee GP, de Souza P and Khachigian LM: Current and potential treatments for cervical cancer. Curr Cancer Drug Targets 13: 205-220, 2013.

27. Olusola P, Banerjee HN, Philley JV and Dasgupta S: Human papilloma virus-associated cervical cancer and health disparities. Cells 8: 622, 2019.

28. Goodman A: HPV testing as a screen for cervical cancer. BMJ 350: h2372, 2015.

29. Tandon M, Vemula SV and Mittal SK: Emerging strategies for EphA2 receptor targeting for cancer therapeutics. Expert Opin Ther Targets 15: 31-51, 2011.

30. Wykosky J and Debinski W: The EphA2 receptor and ephrinA1 ligand in solid tumors: Function and therapeutic targeting. Mol Cancer Res 6: 1795-1806, 2008.

31. Garcia-Monclus S, Lopez-Alemany R, Almacellas-Rabaiget O, Herrero-Martín D, Huertas-Martinez J, Lagares-Tena L, Alba-Pavón P, Hontecillas-Prieto L, Mora J, de Álava E, et al: EphA2 receptor is a key player in the metastatic onset of Ewing sarcoma. Int J Cancer 143: 1188-1201, 2018.

32. Finney AC, Funk SD, Green JM, Yurdagul A Jr, Rana MA, Pistorius R, Henry M, Yurochko A, Pattillo CB, Traylor JG, et al: EphA2 expression regulates inflammation and fibroproliferative remodeling in atherosclerosis. Circulation 136: 566-582, 2017.

33. Abraham S, Knapp DW, Cheng L, Snyder PW, Mittal SK, Bangari DS, Kinch M, Wu L, Dhariwal J and Mohammed SI: Expression of EphA2 and Ephrin A-1 in carcinoma of the urinary bladder. Clin Cancer Res 12: 353-360, 2006.

34. Zhou H, Sun Y, Zhang L, Kang W, Li N and Li Y: The RhoA/ROCK pathway mediates high glucose-induced cardiomyocyte apoptosis via oxidative stress, JNK, and p38MAPK pathways. Diabetes Metab Res Rev 34: e3022, 2018.

35. Yuan J, Chen L, Xiao J, Qi XK, Zhang J, Li X, Wang Z, Lian YF, Xiang T, Zhang Y, et al: SHROOM2 inhibits tumor metastasis through RhoA-ROCK pathway-dependent and -independent mechanisms in nasopharyngeal carcinoma. Cell Death Dis 10: 58, 2019.

36. Li D, Wang H, Ding Y,Zhang Z, Zheng Z, Dong J, Kim H, Meng X, Zhou Q, Zhou J, et al: Targeting the NRF-2/RHOA/ROCK signaling pathway with a novel aziridonin, YD0514, to suppress breast cancer progression and lung metastasis. Cancer Lett 424: 97-108, 2018 
37. He M, Cheng Y, Li W, Liu Q, Liu J, Huang J and Fu X: Vascular endothelial growth factor $\mathrm{C}$ promotes cervical cancer metastasis via up-regulation and activation of RhoA/ROCK- $2 /$ moesin cascade. BMC Cancer 10: 170, 2010.

38. Khumkhrong P, Piboonprai K, Chaichompoo W, Pimtong W, Khongkow M, Namdee K, Jantimaporn A, Japrung D, Asawapirom U, Suksamrarn A and Iempridee T: Crinamine induces apoptosis and inhibits proliferation, migration, and angiogenesis in cervical cancer SiHa cells. Biomolecules 9: 494, 2019.

39. Suprynowicz FA, Upadhyay G, Krawczyk E, Kramer SC, Hebert JD, Liu X, Yuan H, Cheluvaraju C, Clapp PW, Boucher RC Jr, et al: Conditionally reprogrammed cells represent a stem-like state of adult epithelial cells. Proc Natl Acad Sci USA 109: 20035-20040, 2012.

40. Masuda Y, Takahashi $\mathrm{H}$ and Hatakeyama S: TRIM29 regulates the p63-mediated pathway in cervical cancer cells. Biochim Biophys Acta 1853: 2296-2305, 2015.
41. Hazawa M, Lin DC, Handral H, Xu L, Chen Y, Jiang YY, Mayakonda A, Ding LW, Meng X, Sharma A, et al: ZNF750 is a lineage-specific tumour suppressor in squamous cell carcinoma. Oncogene 36: 2243-2254, 2017.

42. Hazawa M, Lin DC, Kobayashi A, Jiang YY, Xu L, Dewi FRP, Mohamed MS, Hartono, Nakada M, Meguro-Horike M, et al: ROCK-dependent phosphorylation of NUP62 regulates p63 nuclear transport and squamous cell carcinoma proliferation. EMBO Rep 19: 73-88, 2018.

(i) (9) This work is licensed under a Creative Commons Attribution-NonCommercial-NoDerivatives 4.0 International (CC BY-NC-ND 4.0) License. 